\title{
ATP2A2 wt Allele
}

National Cancer Institute

\section{Source}

National Cancer Institute. ATP2A2 wt Allele. NCI Thesaurus. Code C106417.

Human ATP2A2 wild-type allele is located in the vicinity of 12q24.11 and is approximately $70 \mathrm{~kb}$ in length. This allele, which encodes sarcoplasmic/endoplasmic reticulum calcium AT Pase 2 protein, is involved in the modulation of cardiac muscle contractility. Mutation of the gene is associated with both Darier disease and acrokeratosis verruciformis. 